\title{
Efektifitas Budaya Literasi dalam Meningkatkan Keterampilan 4C Siswa Sekolah Dasar
}

\author{
Muhammad Fauzan Muttaqin ${ }^{1}$ \& Hofipah Rizkiyah ${ }^{2}$ \\ Institut Daarul Qur'an Jakarta, Indonesia \\ Email: ${ }^{1}$ muhammad.fauzan.muttaqin@gmail.com, \\ ${ }^{2}$ hofipahrizkiyah26@gmail.com
}

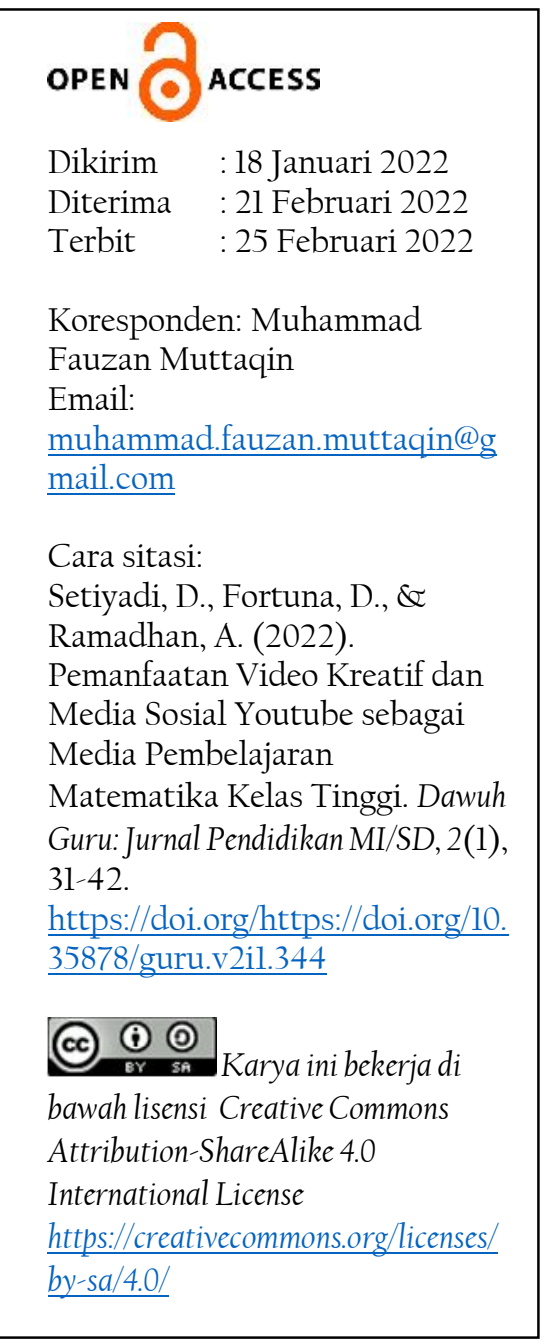

\begin{abstract}
The school literacy movement is a government program that is being intensively implemented. The movement is carried out through a literacy culture. The existence of a literacy culture is very helpful for students in influencing $4 C$ skills in students. This research aims to analyse cultural literacy on students' $4 C$ skills. The research method used is qualitative with a descriptive approach. Data collection techniques using observation, interviews, and documentation. The data analysis used is source triangulation and technique triangulation through data collection, data reduction, data presentation, and data verification/conclusion. The results of the study show that 1) the implementation of a literacy culture that has been running is very effective where literacy culture makes students have good $4 C$ (Communication, Collaboration, Critical Thinking and Problem Solving, and Creativity and Innovation) skills.
\end{abstract}

Keyword: Literacy Culture; 4C Skills; Elementary School

\begin{abstract}
Abstrak
Gerakan literasi sekolah merupakan program pemerintah yang sedang gencar di terapkan. Gerakan tersebut dilaksanakan melalui Budaya literasi. Adanya budaya literasi sangat membantu para siswa dalam mempengaruhi keterampilan 4C pada diri siswa. Tujuan dari
\end{abstract} penelitian ini adalah untuk menganalisis budaya literasi pada keterampilan 4C siswa. Metode yang digunakan penelitian yaitu kualitatif dengan pendekatan deskriptif. Teknik pengumpulan data menggunakan observasi, wawancara, dan 
dokumentasi. Analisis data yang digunakan yaitu triangulasi sumber dan triangulasi teknik di mana melalui proses pengumpulan data, reduksi data, penyajian data, verifikasi data/ kesimpulan. Hasil penelitian menunjukan bahwa penerapan budaya literasi yang sudah berjalan berlangsung sangat efektif budaya literasi membuat para siswa mempunyai keterampilan 4C (Communication, Collaboration, Critical Thinking and Problem Solving, dan Creativity and Innovation) yang baik.

Kata kunci: Budaya Literasi; Keterampilan 4C; Sekolah Dasar

\section{A. Latar Belakang}

Saat ini Indonesia sedang menghadapi wabah Covid 19, sesuai dengan surat edaran dari Kementerian Pendidikan dan Kebudayaan nomor 3 tahun 2020 Tentang Pelaksanaan Pembelajaran di Satuan Pendidikan di Masa Pandemi Covid 19 ini, kegiatan pembelajaran di satuan pembelajaran dilaksanakan secara daring untuk mencegah penyebaran Covid 19. Oleh karena itu, guru dituntut harus menguasai teknologi informasi. Teknologi informasi pada pembelajaran daring di masa pandemi Covid 19 di abad ke-21 ini sangatlah penting dan harus dikuasai oleh siswa maupun guru di sekolah. Hal ini dikarenakan teknologi informasi telah memasuki berbagai dunia pendidikan. Perkembangan ilmu pengetahuan dan teknologi telah menghasilkan berbagai macam kemudahan di dalam proses belajar (Wisada \& Sudarma, 2019).

Abad ke-21 atau yang disebut sebagai abad pengetahuan ialah landasan utama untuk berbagai aspek kehidupan. Pembelajaran abad ke-21 lebih menekankan kemampuan siswa untuk berpikir kritis, mampu menghubungkan ilmu dengan dunia nyata, menguasai teknologi informasi, berkomunikasi, dan berkolaborasi. Pada masa perkembangan awal, literasi didefinisikan sebagai kemampuan untuk menggunakan bahasa dan gambar dalam bentuk yang kaya dan beragam untuk membaca, menulis, mendengarkan, berbicara, melihat, menyajikan, dan berpikir kritis tentang ideide (Abidin, 2018).

Literasi dapat dipahami sebagai suatu kemampuan berbahasa seseorang atau menyampaikan sesuatu (menyimak, berbicara, membaca, dan menulis) untuk melakukan interaksi dengan cara yang berbeda sesuai dengan tujuannya (Sari \& Pujiono, 2017). Berjalannya dengan seiring berkembangnya teknologi informasi dan komunikasi, definisi literasi juga mengalami perkembangan lanjutan yakni literasi dalam generasi kelima. Istilah literasi dalam generasi kelima dikenal pula dengan istilah multiliterasi. Istilah multiliterasi mengandung pengertian sebagai keterampilan menggunakan beragam cara untuk menyatakan dan memahami ide-ide dan informasi, dengan menggunakan bentuk-bentuk teks konvensional maupun teks inovatif, simbol, dan multimedia (Kusuma, 2019). 
Pengertian literasi dalam konteks Gerakan Literasi Sekolah adalah kemampuan mengakses, memahami, dan menggunakan sesuatu secara cerdas melalui berbagai aktivitas antara lain membaca, melihat, menyimak, menulis, dan/atau berbicara. Gerakan Literasi Sekolah (GLS) adalah sebuah upaya yang dilakukan secara menyeluruh dan berkelanjutan untuk menjadikan sekolah sebagai organisasi pembelajaran yang warganya literat sepanjang hayat melalui pelibatan publik (Antasari, 2017). Kemampuan literasi siswa Indonesia yang mewakili masyarakat Indonesia secara umum tergolong rendah, terutama dalam hal literasi bahasa (Kharizmi, 2019).

Berdasarkan hasil observasi awal di SD Negeri petir 4 dan Sekolah SDN Cipondoh 6 terdapat beberapa kendala yang ditemukan terkait dengan rendahnya budaya literasi tersebut, yakni kurangnya motivasi, malas, lelah dan jenuh, kurangnya referensi yang tersedia, sulitnya memunculkan ide untuk menulis, sulitnya merangkai kata dan kalimat. Walaupun demikian, tantangan yang sedang dihadapi dan menjadi sorotan saat ini adalah rendahnya minat baca di kalangan masyarakat termasuk siswa (Surgangga, 2017). Rendahnya minat membaca tentu sangat berdampak pada rendahnya kemampuan literasi membaca. Siswa membaca tapi belum bisa menangkap makna dari apa yang dibacanya. Selain itu, kegiatan membaca dan menulis saling berkaitan (Sari \& Pujiono, 2017).

Literasi lebih dari sekadar membaca dan menulis, namun mencakup keterampilan berpikir menggunakan sumber-sumber pengetahuan dalam bentuk cetak, visual, digital, dan auditori. Literasi dapat dijabarkan menjadi Literasi Dasar (Basic Literacy), Literasi Perpustakaan (Library Literacy), Literasi Media (Media Literacy), Literasi Teknologi (Technology Literacy), Literasi Visual (Visual Literacy). Menurut (Kemendikbud: 2017) Gerakan literasi di sekolah tidak lagi menjadi bagian terpisah/berdiri sendiri dalam pelaksanaannya.

Aktivitas peserta didik di kelas bersama guru guna memperkaya dan memperdalam wawasan serta penguasaan materi, sehingga siswa terlibat langsung tidak lagi hanya bergantung pada guru. Maka dari itu salah satu tahapan gerakan literasi sekolah adalah "Meningkatkan kemampuan literasi di semua mata pelajaran: menggunakan buku pengayaan dan strategi membaca di semua mata pelajaran". Dengan demikian semua guru mata pelajaran untuk di wajib melaksanakan gerakan literasi tersebut dalam pembelajarannya disesuaikan dengan karakteristik mata pelajaran masing-masing.

Kemajuan teknologi informasi, komputer dan internet memberi banyak pilihan yang dapat menunjang kegiatan pembelajaran. Keterampilan abad 21 atau diistilahkan dengan 4C (Communication, Collaboration, Critical Thinking and Problem Solving, dan Creativity and Innovation). Inilah yang sesungguhnya ingin dituju dengan K13 bukan sekadar transfer materi tetapi guru harus melakukan komunikasi dengan baik (Septikasari \& Frasandy, 2018). Pembentukan 
keterampilan 4C sebenarnya kata ini tidak terlalu baru. Di berbagai kesempatan, kita sudah sering mendengar beberapa pakar menjelaskan pentingnya penguasaan 4C sebagai sarana meraih kesuksesan, khususnya di Abad 21 di mana dunia berkembang dengan sangat cepat dan dinamis.

Penerapan keterampilan berpikir kritis dan pemecahan masalah, keterampilan berpikir kritis dan pemecahan masalah dalam proses pembelajaran antara lain dengan (a) Menggunakan beberapa macam tipe penalaran/pemikiran maupun alasan, baik induktif atau deduktif dengan tepat serta sesuai situasi; (b) Memahami interkoneksi antara satu konsep dengan konsep yang lain dalam suatu mata pelajaran, serta keterkaitan antarkonsep antara suatu mata pelajaran dengan mata pelajaran lainnya; (3) Melakukan penilaian serta memutuskan secara efektif dalam mengolah data dan menggunakan argumentasi; (4) Menguji hasil serta membangun koneksi antara informasi dan argumentasi; (5) Mengolah serta menginterpretasi informasi yang didapat melalui kesimpulan awal dan mengujinya lewat analisis terbaik; (6) Membuat solusi dari berbagai permasalahan nonrutin, baik dengan cara yang umum, maupun dengan caranya sendiri; (7) Menggunakan kemampuan yang dimilikinya untuk berusaha menyelesaikan permasalahan; dan (8) Menyusun serta mengungkapkan, menganalisis, maupun menyelesaikan suatu masalah (Kemdikbud: 2017).

Keterampilan dalam berkomunikasi (communication skills dalam proses pembelajaran antara lain mencakup (1) Memahami, mengelola, dan menciptakan komunikasi yang efektif dalam berbagai bentuk dan isi secara lisan, tulisan, dan multimedia (ICT Literacy); (2) Menggunakan kemampuan untuk mengutarakan ide-idenya, baik itu pada saat berdiskusi, di dalam dan di luar kelas, maupun tertuang pada tulisan; (3) Menggunakan bahasa lisan yang sesuai konten dan konteks pembicaraan dengan lawan bicara atau yang diajak berkomunikasi; dan (4) Menggunakan alur pikir yang logis, terstruktur sesuai dengan kaidah yang berlaku (Kemdikbud: 2017).

Keterampilan dalam kreativitas dan inovasi antara lain (1) Memiliki kemampuan dalam mengembangkan, melaksanakan, serta menyampaikan gagasan baru secara lisan maupun tulisan; (2) Bersikap terbuka serta responsif terhadap perspektif baru dan berbeda; (3) Mampu mengemukakan ide kreatif secara konseptual dan praktikal; (4) Menggunakan konsep maupun pengetahuannya dalam situasi baru dan berbeda, baik pada mata pelajaran terkait, antarmata pelajaran, atau dalam persoalan kontekstual; (5) Menggunakan kegagalan sebagai wahana pembelajaran; (6) Memiliki kemampuan dalam menciptakan kebaharuan berdasarkan pengetahuan awal yang dimiliki; dan (7) Mampu beradaptasi pada situasi baru serta memberikan kontribusi positif terhadap lingkungan (Kemdikbud: 2017). 
Keterampilan kolaborasi dalam pembelajaran antara lain (1) Memiliki kemampuan dalam kerjasama berkelompok; (2) Beradaptasi dalam berbagai peran dan tanggung jawab, bekerja secara produktif dengan yang lain; (3) Memiliki empati dan menghormati perspektif berbeda, dan (4) Mampu berkompromi dengan anggota yang lain dalam kelompok demi tercapainya tujuan yang telah ditetapkan (Kemdikbud: 2017).

Pada observasi dan wawancara awalan terdapat beberapa pengajar yang belum bisa menerapkan keterampilan $4 \mathrm{C}$ secara keseluruhan dalam proses pembelajaran yang berlangsung, selain itu kondisi buku yang terdapat di kelas belum terlalu banyak karena satu buku untuk dibaca dua anak. Kondisi yang terdapat di sekolah tersebut menjadi permasalahan yang perlu di teliti dimana budaya literasi menjadi tonggak utama dalam meningkatkan keterampilan $4 \mathrm{C}$ siswa. Selain itu, penelitian yang ada belum terdapat hubungan antara literasi dan keterampilan $4 \mathrm{C}$ pada siswa sehingga sangat penting untuk di analisis lebih mendalam.

\section{B. Metode Penelitian}

Metode penelitian yang digunakan yaitu kualitatif dengan pendekatan deskriptif bertujuan untuk mengetahui peningkatan kemampuan literasi dengan keterampilan 4C. Pada penelitian ini teknik pengumpulan data menggunakan metode wawancara tak terstruktur kepada guru kelas dan siswa dari dua sekolah yaitu SD Negeri Petir 4 dan SDN Cipondoh 6. Kemudian metode dokumentasi yang diamati bukan benda hidup tetapi benda mati (Akhmad, 2015) dilakukan pada saat pembelajaran berlangsung di video, buku-buku yang tersedia, program budaya literasi dan lainnya.

Teknik lainnya yaitu observasi melalui pengamatan secara langsung terhadap gejala-gejala subyek yang diteliti baik pengamatan itu dilakukan dalam situasi sebenarnya maupun dalam situasi yang khusus diadakan (Arikunto, 2016). Observasi dilakukan untuk melihat penerapan keterampilan 4C dan penerapan literasi sebelum dan sesudah pembelajaran, serta di luar kelas dimana mengamati budaya leterasi yang berlangsung di sekolah. Analisis data yang digunakan pada penelitian ini adalah triangulasi sumber dan triangulasi teknik melalui dari proses pengumpulan data, reduksi data, penyajian data, dan penarikan kesimpulan atauverifikasi (Kurniawan \& Sadjiarto, 2013; Megawati, 2016; Rosa, 2015).

\section{Hasil dan Pembahasan}

Mengingat pentingnya pendidikan di era revolusi industri 4.0 ini (Dian \& Pratama, 2019), sekolah memiliki peran penting sebagai tempat memperteguh nilai budaya dan karakter bangsa (Triyanto, Fauziyah, \& Hadi, 2019) untuk mengembangkan wawasan siswa. Hal ini dapat diwujudkan apabila kegiatan pembelajaran di sekolah mampu mendukung terbentuknya siswa yang 
memiliki wawasan yang luas dan mempunyai cara pandang yang internasional. Salah satu cara yang dilakukan adalah dengan mengembangkan budaya literasi di sekolah (Wulandari, 2017).

Perencanaan pengembangan budaya literasi diwujudkan dalam bentuk perumusan tujuan, perumusan program, perumusan strategi, dan pengelolaan sarana dan prasarana (Saadati \& Sadli, 2019). Sementara itu Alfarikh menjelaskan dalam menumbuhkan budaya literasi di kalangan pelajar dengan menggunakan beberapa program, yakni e-pustaka, mentoring kata, dan arisan kata (Alfarikh, 2017). Adanya sarana perpustakaan berfungsi sebagai pusat informatif, sehingga perpustrakaan perlu dilakukan beberapa upaya untuk meningkatkan kualitas perpustakaan sebagai pusat sumber informasi (Darmayanti, 2016).

Membangun tradisi literasi memerlukan pendampingan secara inten yang dapat dilakukan melalui berbagai kegiatan, seperti seminar literasi, pelatihan menulis dan penugasan pembuatan buku (Syahlan et al., 2019). Pendidikan literasi tercermin dalam lima metode pembelajaran yaitu; makanani (terjemahan tatabahasa), bandongan (memaknai teks dengan panduan guru secara bersama-sama/kelompok besar), sorogan (presentasi individu terkait suatu materi), musyawarah (diskusi), dan muhafadoh (hafalan) (Fitriyah et al., 2019). (Dewantara \& Tantri, 2017) menjelaskan bahwa program budaya literasi ini dikemas dengan kegiatan 15 menit membaca sebelum jam pelajaran, melaksanakan sabtu literasi, menata perpustakaan, dan menciptakan lingkungan yang kaya teks.

Hasil observasi dan wawancara tentang budaya literasi di Sekolah SD Negeri Petir 4 pada proses belajar mengajar dilakukan dengan pembiasaan literasi sebelum kegiatan belajar belajar maka siswa-siswi diwajibkan untuk membaca buku terlebih dahulu selama 10 menit dansudah menjadi budaya siswa dalam keseharian. Pada saat membaca buku siswa dengan senang dan khidmat membacanya. Proses belajar mengajar guru memberikan kesempatan kepada siswa-siswi untuk berani dalam hal diskusi dan memberikan pendapatnya, maka dari itu siswa-siswi diberikan kesempatan maju di depan kelas untuk melatih mental dan keberanian siswa-siswi. Sekolah SDN Cipondoh 6 juga menerapkan hal tersebut secara efektif dengan membiasakan membaca bersama di dalam kelas. Maka menerapkan hal tersebut guru yang menjadi mentor dalam memulai membaca sebelum belajar, siswa-siswi dengan semangat membaca karena sudah dibiasakan semenjak masuk kelas.

Budaya literasi yang dikembangkan ditujukan untuk melakukan kebiasaan berpikir kritis yang disertai dengan proses membaca dan menulis, yang pada akhirnya proses kegiatan tersebut akan menciptakan sebuah karya (Mursalim, 2017) dimana semakin meningkatkan minat baca dan tulis para siswa (Syahlan et al., 2019). Salah satu bentuk pembelajaran yang 
meningkatkan kemampuan berfikir tingkat tinggi dan ketrampilan 4C (critical thinking, creative, collaborative, dan commnicative) (Putra, \& Nurlizawati: 2019) melalui kegiatan budaya literasi yang baik. Berdasarkan hasil observasi dan wawancara Budaya literasi yang terdapat di sekolah terdapat kemanpuan 4C tersebut pada para siswa. Selain itu, terdapat pengaruh implementasi pembelajaran saintifik berbasis keterampilan belajar dan berinovasi 4C terhadap hasil belajar peserta didik (Meilani, Dantes, \& Tika, 2020).

Guru menerapkan keterampilan 4C dalam pembelajaran dan mewajibkan siswa untuk mencari literasi buku untuk mencari informasi tambahan. Pada proses pembelajaran yang menerapkan budaya leterasi di sekolah, para siswa nampak memiliki karakter sebagai seorang pemikir, cakap dalam berpikir kreatif inovatif yang ditandai dengan kemampuan beradaptasi yang tinggi, mampu memecahkan kompleksitas masalah, pengendalian diri yang kuat dan dapat mengarahkan diri sendiri. Hasil observasi dan dokumentasi juga mendapatkan hasil bahwa para siswa yang sudah menerapkan budaya literasi pada dirinya kecendrungan memiliki karakter kreatif, inovatif, dan memiliki motivasi yang tinggi dalam proses pembelajaran serta cerdas dan berani mengambil resiko.

Maka dari itu, budaya literasi sangatlah penting terutama dalam mencari literasi-literasi informasi. Literasi informasi dipandang dari tiga aspek, yaitu: menyadari keperluan informasi, penelusuran dan penggunaan informasi, dimana para siswa sudah banyak yang mengenal cara-cara bagaimana menelusuri dan menggunakan informasi yang mereka butuhkan(Anwar et al., 2017). Budaya literasi memberikan pengaruh positif yang signifikan antara budaya membaca dengan kemampuan berpikir kritis siswa (Muhammad et al., 2019). Literasi sangat membantu para siswa dalam membentuk kecakapan dalam berkomunikasi, dimana membantu para siswa pada kemampuan bekerja dalam tim yang bervariasi, berkolaborasi, dan cakap mengembangkan hubungan interpersonal sehingga selalu dapat menempatkan diri dalam interaksi yang harmonis.

Budaya literasi membuat para siswa memiliki kecakapan komunikasi personal, sosial, dan terampil melaksanakan tanggung jawab. Yang tidak kalah penting siswa menjadi terampil dalam komunikasi interaktif dengan cerdas dan rendah hati. Dengan penerapan budaya literasi, para siswa dapat mengembangkan keterampilan yang dimilikinya. Keterampilan tersebut yakni bekerja secara kreatif dengan orang lain seperti keterampilan mengembangkan, melaksanakan, dan mengomunikasikan idenya secara efektif kepada orang lain, serta keterampialn untuk menerima pendapat dan masukan serta menerapkannya dalam kerja kelompok.

Budaya literasi di sekolah yang sudah berjalan dengan efektif dalam keseharian. Para siswa sangan senant dalam menjalankan literasi pada proses 
pembelajaran dan di waktu lainya seperti sebelum mulai kegiatan pembelajaran, istirahat, dan setelah selesai pembelajaran sambal menunggu jemputan dari orang tua siswa. Keefektifan budaya literasi yang sudah berjalan tentunya berdampak pada ketrampilan $4 \mathrm{C}$ siswa dengan baik.

\section{Kesimpulan}

Berdasarkan hasil penelitian disimpulkan bahwa penerapan budaya literasi yang sudah berjalan berlangsung sangat efektif dalam meningkatkan keterampilan 4C (Communication, Collaboration, Critical Thinking and Problem Solving, dan Creativity and Innovation) siswa. Penerapan budaya literasi bagi siswa sekolah dasar mampu meningkatkan keterampilan siswa sesuai abad 21. Saran pada penelitian selanjutnya, lebih kepada menganalisis literasi secara spesifik terhadap masing-masing poin $4 \mathrm{C}$ sehingga hasilnya lebih banyak dan valid.

$* * * * * * * * *$

\section{Daftar Pustaka}

Abidin, Y. (2018). Pembelajaran Multi Literasi. Jakarta: Refika Aditama.

Akhmad, K. A. (2015). Pemanfaatan media sosial bagi pengembangan pemasaran UMKM (Studi deskriptif kualitatif pada distro di Kota Surakarta). Dutacom, 9(1), 43-43..

Antasari, I. W. (2017). Implementasi Gerakan Literasi Sekolah Tahap Pembiasaan di MI Muhammadiyah Gandatapa Sumbang Banyumas. Libria, 9(1).

Anwar, R. K., Komariah, N., \& Rahman, M. T. (2017). Pengembangan Konsep Literasi Informasi Santri: Kajian di Pesantren Arafah Cililin Bandung Barat. Wawasan: Jurnal Ilmiah Agama dan Sosial Budaya, 2(1), 131-142.

Arikunto, S. (2016). Prosedur Penelitian Suatu Pendekatan Praktik, Jakarta: Rineka Cipta.

Baharun, H., \& Rizqiyah, L. (2020). Melejitkan Ghirah Belajar Santri melalui Budaya Literasi di Pondok Pesantren. Tadris: Jurnal Pendidikan Islam, 15(1), 108-117.

Darmayanti, R. (2016). Membangun budaya literasi informasi bagi masyarakat kampus. IQRA: Jurnal Ilmu Perpustakaan dan Informasi (e-Journal), 10(1), 92101.

Dewantara, I. P. M., \& Tantri, A. A. S. (2017). Keefektifan budaya literasi di SD N 3 Banjar Jawa untuk meningkatkan minat baca. Journal of Education Research and Evaluation, 1(4), 204-209. 
Fitriyah, L., Marlina, M., \& Suryani, S. (2019). Pendidikan Literasi pada Pembelajaran Kitab Kuning di Pondok Pesantren Nurul Huda Sukaraja. Titian Ilmu: Jurnal Ilmiah Multi Sciences, 11(1), 20-30.

Fitriyah, L., Marlina, M., \& Suryani, S. (2019). Pendidikan Literasi pada Pembelajaran Kitab Kuning di Pondok Pesantren Nurul Huda Sukaraja. Titian Ilmu: Jurnal Ilmiah Multi Sciences, 11 (1), 20-30.

Hadi, M. S. (2020). Peningkatan Kompetensi Guru dalam Menyusun RPP Berbasis PPK, Literasi, 4C, dan HOTS di SMPN 2 Dampit Kabupaten Malang Tahun Pelajaran 2018/2019. Warta Pendidikan | e-Journal, 4(7), 33-40.

Handayani, S. L., \& Amirullah, G. (2019). Meningkatkan pemahaman guru Sekolah Dasar melalui pelatihan penyusunan Rencana Pelaksanaan Pembelajaran berbasis literasi, 4C, PPK dan HOTS. Jurnal Solma, 8(1), 1423.

Indrawati, F. A., \& Wardono, W. (2019, February). Pengaruh Self Efficacy Terhadap Kemampuan Literasi Matematika dan Pembentukan Kemampuan 4C. In PRISMA, Prosiding Seminar Nasional Matematika (Vol. 2, pp. 247-267).

Kemdikbud. (2017). Panduan Gerakan Literasi Nasional. Jakarta: Tim GLN Kemdikbud.

Kemendikbud. (2017). "Penguatan Pendidikan Karakter Jadi Pintu Masuk Pembenahan Pendidikan Nasional". (https://www.kemdikbud.go.id/main/ blog/2017/07/penguatan-pendidikan-karakter-jadi-pintu-masuk-

pembenahan -pendidikan-nasional). Diakses pada hari Minggu, 10 November 2019 pukul 9.22 WIB.

Kharizmi, Muhammad. "Kesulitan Siswa Sekolah Dasar Dalam Meningkatkan Kemampuan

Kurniawan, C., \& Sadjiarto, A. (2013). Pemahaman Kode Etik Ikatan Konsultan Pajak Mengenai Hubungan dengan Wajib Pajak oleh Konsultan Pajak di Surabaya. Tax \& Accounting Review, 1(1), 55.

Kusuma Dewi, A. (2019). Pengembangan Kompetensi Multiliterasi Desain Berbasis Pada Penerapan Tradisi Komunikasi Di Era Indonesia 4.0. Jurnal Desain Indonesia, 1(1), 1-6.

Literasi." Jurnal Pendidikan Almuslim 7, no. 2 (2019).

Megawati, F. (2016). Kesulitan mahasiswa dalam mencapai pembelajaran bahasa Inggris secara efektif. PEDAGOGIA: Jurnal pendidikan, 5(2), 147-156..

Meilani, D., Dantes, N., \& Tika, I. N. (2020). Pengaruh Implementasi Pembelajaran Saintifik Berbasis Keterampilan Belajar dan Berinovasi 4C terhadap Hasil Belajar IPA dengan Kovariabel Sikap Ilmiah pada Peserta Didik Kelas V SD Gugus 15 Kecamatan Buleleng. Jurnal Elementary: Kajian Teori Dan Hasil Penelitian Pendidikan Sekolah Dasar, 3(1), 1-5. 
Muhammad, E. B., Sholichah, A. S., \& Aziz, J. A. (2019). Pengaruh budaya membaca terhadap kemampuan berpikir kritis siswa di SMP Islam Al Syukro Universal Ciputat tahun 2019. Andragogi: Jurnal Pendidikan Islam dan Manajemen Pendidikan Islam, 1(2), 332-343.

Mulyana, D. (2008). Metodologi Penelitian Kualitatif (Paradigma baru ilmu komunikasi dan ilmu sosial lainnya). Bandung: PT. Remaja Rosdakarya.

Mursalim, M. (2017). Penumbuhan Budaya Literasi dengan Penerapan Ilmu Keterampilan Berbahasa (Membaca dan Menulis).

Pratama, D. A. N. (2019). Tantangan Karakter Di Era Revolusi Industri 4.0 Dalam Membentuk Kepribadian Muslim. Al-Tanzim: Jurnal Manajemen Pendidikan Islam, 3(1), 198-226.

Putra, D. M., \& Nurlizawati, N. (2019). Lesson Study dalam Meningkatkan Ketrampilan 4C (Critical Thingking, Collaborative, Communicative dan Creative) pada Pembelajaran Sosiologi yang Terintegrasi ABS-SBK di SMAN 1 Pasaman. Jurnal Sikola: Jurnal Kajian Pendidikan dan Pembelajaran, 1(2), 139-146.

Saadati, B. A., \& Sadli, M. (2019). Analisis pengembangan budaya literasi dalam meningkatkan minat membaca siswa di sekolah dasar. TERAMPIL: Jurnal Pendidikan dan Pembelajaran Dasar, 6(2), 151-164.

Saputri, G. L., Wardono, W., \& Karisudin, I. (2019, February). Pentingnya Kemampuan Literasi Matematika dan Pembentukan Kemampuan 4C dengan Strategi REACT (Relating, Experiencing, Applying, Cooperating, Transferring). In PRISMA, Prosiding Seminar Nasional Matematika (Vol. 2, pp. 563-571).

Sari, E. S., \& Pujiono, S. (2017). Budaya Literasi di Kalangan Mahasiswa FBS UNY. Litera, 16(1).

Septikasari, R., \& Frasandy, R. N. (2018). Keterampilan 4C abad 21 dalam pembelajaran pendidikan dasar. Tarbiyah al-Awlad, 8(2), 107-117.

Sriyanto, Budi. (2021). "Meningkatkan Keterampilan 4c Dengan Literasi Digital Di Smp Negeri 1 Sidoharjo.". Jurnal Didaktika Pendidikan Dasar. 5 (1): 125142.

Suragangga, I. M. N. (2017). Mendidik lewat literasi untuk pendidikan berkualitas. Jurnal Penjaminan Mutu, 3(2), 154-163.

Syahlan, T., Imron, A., \& Zulfa, L. N. (2019). Pendampingan Santri untuk Membangun Tradisi Literasi Di Pondok Pesantren Al-Mubarok Mranggen Demak. Dimas: Jurnal Pemikiran Agama untuk Pemberdayaan, 19(1), 49-60. 
Triyanto, T., Fauziyah, F. A., \& Hadi, M. T. (2019). Bahasa Sebagai Pendidikan Budaya Dan Karakter Bangsa. Jurnal Salaka: Jurnal Bahasa, Sastra, dan Budaya Indonesia, 1(1).

Valls-Pedret, C., Lamuela-Raventós, R. M., Medina-Remón, A., Quintana, M., Corella, D., Pintó, X., ... \& Ros, E. (2012). Polyphenol-rich foods in the Mediterranean diet are associated with better cognitive function in elderly subjects at high cardiovascular risk. Journal of Alzheimer's Disease, 29(4), 773782 .

Wisada, P. D., \& Sudarma, I. K. (2019). Pengembangan media video pembelajaran berorientasi pendidikan karakter. Journal of Education Technology, 3(3), 140146.

Wulandari, R. (2017). Implementasi kebijakan gerakan literasi sekolah di sekolah dasar islam terpadu lukman aL hakim internasional. Spektrum Analisis Kebijakan Pendidikan, 6(3), 319-330. 
Efektifitas Budaya Literasi dalam Meningkatkan Keterampilan 4C... 